\title{
Characterization of Pollen-Quantitative, Bromatological and Physicochemical of Honeys Commercialized in Nuevo Leon, Mexico
}

\author{
Marco A Alvarado Vázquez*, Alejandra Rocha Estrada, Denisse M Rosales Carrillo, Marco A Guzman Lucio \\ Department of Botany, Autonomous University of Nuevo Leon, C.P. 66451, San Nicolas de los Garza, Nuevo Mexico Leon
}

\begin{abstract}
Honey is a natural sweet substance produced by bees from plant nectar or secretions from live plant parts or from plant-sucking insect excretions. Bees collect, transform and combine these with their own specific substances and deposit, dehydrate, store and leave them on the hive to mature and age. Mexico is the fourth largest honey producer in the world. Eight honey samples were studied considering aspects palynological, bromatological and physicochemical. Regarding pollen richness, these honeys belong to Class II and III, which correspond to pollen-rich honeys. Regarding moisture, values from $10.55 \%$ for S1 honey to $18.14 \%$ for LC were found. For ash, LC honey had a lower percentage $(0.07 \%)$ while EM honey had a greater percentage $(0.42 \%)$. A maximum protein value of $0.63 \%$ was found, corresponding to EC honey. All the honeys analyzed were within the reference values $(89.29 \%$ for honey S2 and $81.66 \%$ for LC) for nitrogen-free extract. Regarding ethereal extract, values of $0.01 \%$ and $0.08 \%$ were found while water activity $\left(\mathrm{a}_{\mathrm{w}}\right)$ in the honey had values from 0.55 to 0.65 . The $\mathrm{pH}$ of the honeys was between 3.73 and 4.16 . The electrical conductivity of the honeys analyzed was between 0.27 and $0.50 \mathrm{mS} / \mathrm{cm}$. Reducing sugars content was between 63.72 and $84.33 \%$, corresponding to EC and ADA honeys, respectively. The results of this study indicate that the honeys analyzed are within the National and International standards.
\end{abstract}

Keywords: Honey; Pollen; Nuevo Leon; Mexico

\section{INTRODUCTION}

Honey is a natural sweet substance produced by the Apis mellifera bee or by different subspecies, from flower nectar and other extra floral excretions that bees absorb, transport, transform, combine with other substances, dehydrate, concentrate, and store in their hives [1-3].

The use of honey as food goes back to prehistory. Man would extract honey from beehives found in empty tree trunks or cracks in rock. Since then and to date, it is a very important food since it has therapeutic properties as well as other properties that directly help the food industry [4]. Its composition is complex and carbohydrates represent the greatest proportion, highlighting mainly fructose and glucose, although it contains a large variety of minor substances, such as enzymes, amino acids, organic acids, antioxidants, and vitamins and minerals [3].

Honey production in Mexico is a predominant activity in the cattle sector of the country where it generates a large number of jobs and it is the second most important source of income in the cattle sector. The aroma, flavor and color of Mexican honey make it have a great demand in European countries as well as in the United States [5]. Mexico is the fourth largest producer of honey and the third exporter of honey in the world after China and the United States [6]. There are parameters that determine its quality and these are its physical and chemical composition. Regarding its physical composition, color, flavor, aroma, texture and moisture are considered. With regard to its chemical composition, carbohydrates, acids, proteins and amino acids, minerals and hydroxymethylfurfural are found [7].

Recently, the demand for natural products differentiated by their quality has increased and among these products is honey. Honeys, typified by their botanical and geographic origin, have a strong demand in countries that are traditional honey consumers, such as Japan and Germany, and also in other countries where consumption was not relevant until now, such as in Arab countries; therefore, the study of honey pollen has become very important [4].

Studies carried out on honey in the world have focused mainly on different areas of Central Europe, where there are countries in which almost all types of honey from regions where beekeeping develops have been described. In contrast, in Latin America, these

${ }^{*}$ Correspondence to: Alvarado Vázquez MA, Department of Botany, Autonomous University of Nuevo Leon, C.P. 66451, San Nicolas de los Garza, Nuevo Leon, Mexico, Tel: +52(81)83-29-4110; E-mail: marco.alvaradovz@uanl.edu.mx

Received: March 20, 2019; Accepted: June 27, 2019; Published: July 04, 2019

Citation: Alvarado Vázquez MA, Estrada AR, Rosales Carrillo DM, Guzman Lucio MA (2019) Characterization of Pollen-Quantitative, Bromatological and Physicochemical of Honeys Commercialized in Nuevo Leon, Mexico. Biochem Anal Biochem 8:383. doi: 10.35248/2161-1009.19.8.383.

Copyright: (C) 2019 Alvarado Vázquez MA, et al. This is an open-access article distributed under the terms of the Creative Commons Attribution License, which permits unrestricted use, distribution, and reproduction in any medium, provided the original author and source are credited. 
studies are scarce; however, Argentina, Brazil, Mexico and Uruguay present an important degree of development and transfer in production. Honey, because of its great nutritional value, unique flavor, and recognized characteristics, has been used as food and as a natural sweetener instead of cane sugar and artificial sweeteners. Because of this, honey can be adulterated to reduce production costs. For this reason, several countries have implemented strict standards for commercializing honey, including its physicalchemical and botanical properties [8]. Therefore, the aim of this research was to know the pollen richness and determine the main physical-chemical properties that characterize the honey that is produced and commercialized in the state of Nuevo Leon.

\section{MATERIALS AND METHODS}

\section{Sample collection}

Eight honey samples were obtained directly from the hives in the apiaries of the cities from the beekeeping region of the state of Nuevo Leon and from convenience stores. The amount of honey obtained from the locations was $500 \mathrm{~g}$ and all the honey samples were stored at ambient temperatura until analyzed.

\section{Quantitative pollen analysis}

This was performed in the following way: Approximately $0.02 \mathrm{~g}$ of previously homogenized honey was placed on a scale. Afterwards, a cover slip was placed over the sample and it was analyzed with a microscope. All the pollen grains in the honeys were counted, and then the total pollen grains were expressed for $10 \mathrm{~g}$ of honey and were classified according to the Demianowicz method (1955) in [1] into five categories, with these being described as honey extremely poor in pollen, honey rich in pollen, or honey extremely rich in pollen.

\section{Bromatological and physicochemical analysis}

Moisture content: Three grams of honey were weighed and placed in a previously weighed crucible. The sample was dried to a constant weight in a vacuum oven at $105^{\circ} \mathrm{C}$ for four hours [9].

Determination of ash content: One gram of sample was previously weighed separately in a porcelain crucible; the sample was burned in front of a fume hood. The crucible was placed in a muffled furnace and maintained at $600^{\circ} \mathrm{C}$ for 6 hours. It was allowed to dry in a desiccator and was immediately weighed [9]. The percentage of ash was calculated thus:

$\%$ ashes $=\frac{(\text { crucible weight }+ \text { ashes })-(\text { empty crucible weight }) \times 100}{\text { Sample weight }}$

Determination of proteins: This method is based on the destruction of organic matter with concentrated sulfuric acid, forming ammonium sulfate, which in excess of sodium hydroxide releases ammonia; this is distilled by receiving it in sulfuric acid where ammonium sulfate is formed and the excess of acid is titrated with sodium hydroxide in the presence of methyl red or boric acid forming ammonium borate, which is evaluated with hydrochloric acid [9]. Calculation and expression of results:

$\% N=\frac{14 \times N \times V \times 100}{m \times 1000}$

$\%$ Protein $=\frac{14 \times N \times V 100 \times \text { Correction factor }}{m \times 1000}$

Correction factor is 6.25 .
Determination of nitrogen-free extract: This is obtained as the result of subtracting the calculated percentages for each nutrient from 100 [9].

\section{$\%$ NFE $=100 \%-(\%$ moisture+\%protein+\%lipids+\%ash)}

Determination of ethereal extract: In this method, fat is extracted with petroleum ether and evaluated as percentage of weight after evaporating the solvent [9].

Determination of $\mathrm{pH}$ : Twenty grams of honey is weighed and diluted in $50 \mathrm{~mL}$ of water; the potentiometer is calibrated with buffer solution with a $\mathrm{pH}$ of 4 and 7 ; afterwards, the determination of the samples is made [7].

Determination of $a_{w}$ : For the determination of this parameter, Aqualab equipment was used. The procedure for this determination was carried out according to the user's manual. The equipment is turned on and calibrated for 15 minutes with a special plastic sample cup for Aqualab; this sample cup is without a sample. Once calibrated, one gram of sample is placed in the plastic sample cup and the procedure is performed in triplicate; the $a_{w}$ value is measured directly until three consecutive readings of each sample are made.

Determination of acidity according to the Bianchi method: This is based on an acid neutralization process using a hydroxide in the presence of an internal indicator, phenolphthalein [10]. Ten grams of honey are weighed and dissolved in $75 \mathrm{~mL}$ of distilled water. The solution is titrated with sodium hydroxide $0.1 \mathrm{~N}$, using phenolphthalein as an indicator. The result is expressed in milliequivalents of acid per kilogram of honey and it is calculated in the following way:

Acidity $=10 \times \mathrm{V}$

Determination of the reducing sugars: This was performed according to the Layne-Enyon method described in AOAC [11].

Determination of electrical conductivity: There is a lineal relationship between ash content and electrical conductivity. The formula that allows the establishment of the relation between conductivity and ash is the following:

$\mathrm{C}=0.14+1.74 \times$ ash content

Presence of dextrins: Approximately one gram of honey is placed in a $50 \mathrm{~mL}$ beaker; $4 \mathrm{~mL}$ of distilled water is added and the honey is completely dissolved. From this solution, $2 \mathrm{~mL}$ are taken and placed in a test tube and $1 \mathrm{~mL}$ of ethanol is added. If the solution remains clean, the honey is not adulterated, but if the solution becomes milky-white, the honey is adulterated [12].

\section{RESULTS AND DISCUSSION}

\section{Quantitative pollen analysis}

Honey classes were determined according to Maurizio [1]. It was found that the honeys studied are rich in pollen. The majority are included in Class II, such as EM, S1, S2 and $\mathrm{PH}$, while honeys such as LC, ADA and C1 are in Class III, with EC honey being the only honey belonging to Class I, corresponding to honey that is extremely poor in pollen (Table 1).

These differences are due to factors that can vary the pollen content among honeys. Among these are the flower morphology, the position of the nectaries, the position and number of stamens, the separation of the gynoecium from the stamen, the scarcity of 
Table 1: Honey classes according to Maurizio [1].

\begin{tabular}{ccc}
\hline Honey sample & Pollen $/ 10 \mathrm{~g}$ Honey & Class \\
\hline LC & 102944 & III \\
\hline ADA & 102886 & III \\
\hline EM & 98273 & II \\
\hline EC & 19023 & I \\
\hline S1 & 53250 & II \\
\hline S2 & 59016 & II \\
\hline PH & 37391 & II \\
\hline C1 & 217914 & III \\
\hline
\end{tabular}

I: Extremely poor honey in pollen, <20,000; II: 20,000-100,000; III: Pollen rich honey, 100,000-500,000; IV: 500,000-1,000,000; V: Honey extremely rich in pollen, >1,000,000.

pollen in hybrid plants, the pollen morphology, the distance to the source of nectar, apicultural practices, fraudulent pollen additions, and climate [13]. In addition, the variations in the absolute number of pollen grains that honeys have are linked to the foraging of bees and depend on the floral physiology and morphology, the amount of pollen grains collected in each anther and the flower phenology [14].

On the other hand, the origin of pollen found in honey comes from pollen grains that have fallen into the nectar in bloom, whether due to the wind or movement caused by the insect, liberating mature pollen grains from the anthers, which fall into the nectar. The nectar is then gathered by the bees and taken into the hive where it is deposited into wax cells to mature and form honey; the pollen grains remain contained in the cells [1].

The importance of this type of classification rests on the fact that international markets pay more for honey that complies with European quality control standards. Foremost among these is the pollen grain content of honeys (melissopalynology). Since Mexico does not possess this type of studies, its exportations do not have the added value that would result from the certification of the floral origin of its honeys with a melissopalynology basis. Mexico, because of its climate and floral diversity, has several honey producing regions with different types of honeys with a great variety of flavors, aromas and colors, which are well priced in international markets; therefore, it would be highly recommendable for the national apiculture industry to be aware of the need of selling their honey as an elaborated product with the added value that melissopalynology analysis provides so they can label their products as unifloral or multifloral honey with the names of the different plants that they come from [14].

\section{Bromatological analysis}

Bromatological analysis is of vital importance for the determination of quality parameters of honey because it allows the identification of foods and also recognizes the physical and chemical adulterations that a food can suffer, in addition to the physical and chemical changes that occur when being transformed, either for conservation or consumption purposes [15].

Moisture content: The moisture in honey is an important parameter because it is related to the quality of the product, the direct conservation of the product with time, and also with the flora and climate of the geographical area from where it comes [16]. Honey is a food with intermediate moisture. Its water content varies between $14 \%$ and $20 \%$ depending on the climate, the time of year, the initial moisture of the nectar, and the degree of maturity reached in the hive as well as it biogeographic origin. The variation in moisture intervenes in granulation phenomena and defines the stability of the product from a microbiological point of view; therefore, the water content in honey is one of the most important characteristics that determine its degree of conservation. Moisture can increase during extraction and storage due to the hygroscopic properties of honey [17].

Furthermore, it is important in the fermentation process of honey. This is produced by osmophillic bacteria that act under certain conditions. Mature honey normally has a moisture content of $18.5 \%$, and when it exceeds this level, it is susceptible to fermentation [3]. Also, a high percentage of water favors the development of molds and yeasts, and honey with a high percentage of water easily ferments [18]. According to the Mexican Standard for Honey, the moisture content should not be greater than $20 \%$ [19]. The analyzed honeys were compared to this standard. The analyzed honey samples were within the standard since they comply with this parameter. The honey with the lowest moisture value was S2 (10.55\%), while the honey with the highest percentage of moisture was LC with $18.14 \%$ (Table 2, Figure 1).

Studies carried out in honeys from departments of the province of Corrientes in Argentina had moisture percentages that surpassed the MERCOSUR Standards and Regulations, which establish $20 \%$ as the highest level of moisture allowed. The samples analyzed exceeded this parameter, thus, these honeys are in danger of fermentation during storage due to the activity of osmophillic bacteria [16]. It is known that in honeys the moisture parameter is one of the most important since it greatly influences the sensory aspects of honey, mainly granulation and flavor. It also intervenes in the fermentation process, an alteration that honey can suffer when moisture exceeds $18 \%$ [16].

Ash content: Minerals in honey are found in traces with potassium being the most abundant. Dark honeys, especially honeydew honeys, are rich in minerals. The mineral content influences the color of honey as well as its flavor, since a greater mineral content produces a darker color and a flavor with greater intensity [20]. Ashes are the inorganic result that remains after cooking honey to a temperature of $550^{\circ} \mathrm{C}$. It is formed by numerous mineral elements that come from plant nectar and/or the honey source and the pollen contained in the honey [21]. The measure of ashes is related to problems of hygiene (earth and sand). Honey adulterated with molasses can also have a high percentage of ashes [18]. According to the Mexican Honey Standard (NMX-F-036-NORMEX-2006Food Specifications and Testing Methods), the percentage of ashes should not be greater than $0.6 \%(\mathrm{~g} / 100 \mathrm{~g})$. In the analyzed honeys, this parameter was not exceeded. LC honey had the lowest percentage $(0.07 \%)$, while EM honey had the greatest percentage $(0.42 \%)$ (Table 2, Figure 1$)$. On the other hand, Torrente García [22] mentioned that the presence of minerals influences the color and flavor of honeys; therefore, honeys with a greater amount of ashes are darker and have a stronger taste.

Protein content: The relative amount of protein in honey is considered an index of its quality [23]. Honey only contains nitrogen in amino acids and proteins in the range of $0-0.13 \%$ with an average of $0.04 \%$; in other words, its nutritional value is almost insignificant, Crane, 1990 in [24]. On the other hand, Suescun and Vit [17] mention a range of $0.2-2 \%$ of protein and amino acids. Regarding the results found in the honeys we studied, a maximum value of $0.63 \%$ was found corresponding to EC honey; also, the 
Table 2: Proximate composition of honey samples.

\begin{tabular}{cccccc}
\hline Honey sample & Moisture (\%) & Ash (\%) & Protein (\%) & EE (\%) & NFE (\%) \\
\hline LC & $18.14 \pm 0.17$ & $0.08 \pm 0.1$ & $0.12 \pm 0.00$ & $0.01 \pm 0.00$ & $81.66 \pm 0.18$ \\
\hline ADA & $16.10 \pm 0.04$ & $0.12 \pm 0.00$ & $0.24 \pm 0.00$ & $0.04 \pm 0.01$ & $83.50 \pm 0.04$ \\
\hline EM & $17.4 \pm 0.17$ & $0.21 \pm 0.01$ & $0.29 \pm 0.11$ & $0.09 \pm 0.01$ & $82.01 \pm 0.04$ \\
\hline EC & $15.67 \pm 0.01$ & $0.19 \pm 0.01$ & $0.63 \pm 0.06$ & $0.04 \pm 0.01$ & $83.47 \pm 0.07$ \\
\hline S1 & $12.11 \pm 0.17$ & $0.16 \pm 0.02$ & $<0.01 \pm 0.00$ & $0.07 \pm 0.01$ & $87.66 \pm 0.14$ \\
\hline S2 & $10.55 \pm 0.03$ & $0.15 \pm 0.01$ & $<0.01 \pm 0.00$ & $0.02 \pm 0.00$ & $89.28 \pm 0.02$ \\
\hline PH & $14.64 \pm 0.26$ & $0.12 \pm 0.01$ & $<0.01 \pm 0.00$ & $0.04 \pm 0.01$ & $85.20 \pm 0.28$ \\
\hline C1 & $12.6 \pm 0.11$ & $0.11 \pm 0.01$ & $0.01 \pm 0.00$ & $0.04 \pm 0.02$ & $87.24 \pm 0.12$ \\
\hline
\end{tabular}

EE: Ether Extract; NFE: Nitrogen Free Extract
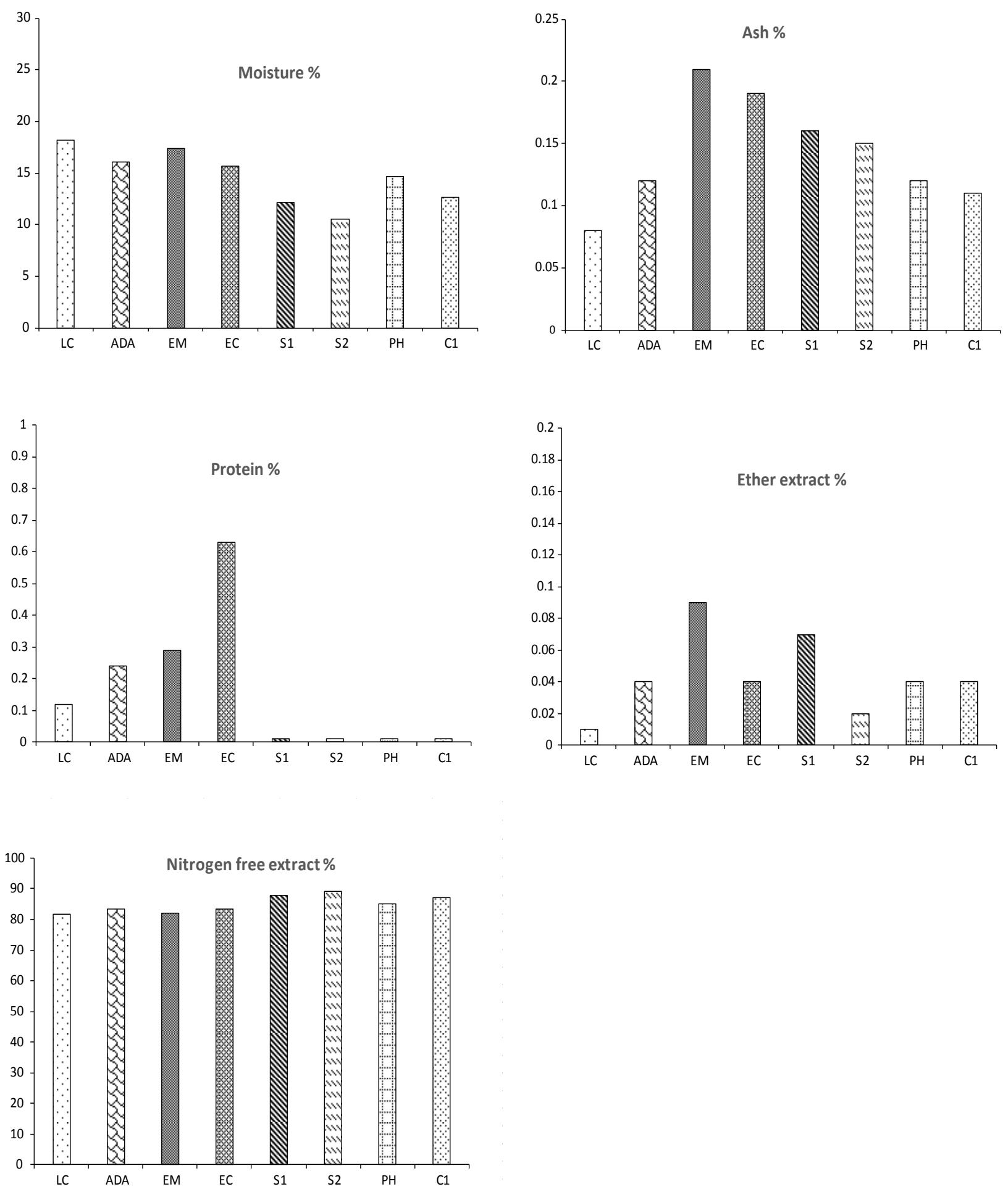

Figure 1: Proximate composition of eight honey samples in Nuevo Leon. 
honeys ADA and EM presented values greater than those reported in the literature (Table 2, Figure 1).

Nitrogen-free extract content: The nitrogen-free extract (NFE) represents the fraction of soluble food carbohydrates (simple sugars and starch). Carbohydrates are the main components of honey. Carbohydrates are sugars with honey being a mixture of carbohydrates, and one of the most complex in nature. These components comprise 75 to $80 \%$ of the total components in honey. These define its characteristics of hygroscopicity, viscosity and low $\mathrm{a}_{\mathrm{w}}[17,25-28]$. Ferrero et al. [27] mention that sugars are the main components of honey, representing approximately $80 \%$ of the total, and 95 to $99 \%$ of the total solids. Sugars represent between 95 and $99 \%$ of the dry matter in honey with most being simple sugars $(85-95 \%)$, such as fructose and glucose. Generally, fructose is more abundant than glucose. Honey also possesses small amounts of disaccharides (sacarose, maltose and isomaltose), trisaccharides and oligosaccharides. Moreover, sugars provide information on the origin of the honey and its adulteration [29]. Regarding the results obtained for the studied honeys, we found that all are within the reference values with $89.29 \%$ for S2 and $81.66 \%$ for LC (Table 2, Figure 1).

Ethereal extract content: With respect to the ethereal extract (EE), values between $0.01 \%$ and $0.08 \%$ were found in the analyzed honeys (Table 2, Figure 1). If traces are found, it is probably due to wax particles that enter during the extraction phase, which, because they are very small, are not eliminated with filtration [30].

\section{Determination of $\mathrm{a}_{\mathrm{w}}, \mathrm{pH}$, acidity, dextrins, reducing sugars and electrical conductivity}

The $a_{w}$ of foods is an important quality factor since it is related to their conservation; however, it is not considered in food technology despite being a quality control factor [31]. In the last three decades, $a_{w}$ has been used as an indicator of stability in food quality control in deterioration processes, among which is the microbiological aspect (Alcalá, 1977 in [31]). a refers to the water levels available in foods. It is the water that is not chemically linked and which is available for microorganisms [32]. According to Bush and Keener [32], the $\mathrm{a}_{\mathrm{w}}$ of honey varies from 0.75 to 0.90 . For the honeys in this study, $a_{w}$ values of 0.55 to 0.65 were found (Table 3, Figure 2). Studies carried out in honey by Bocayá and Tolima (Colombia) found that $\mathrm{a}_{\mathrm{w}}$ varied from 0.57 to 0.59 , considering it a food with intermediate moisture. Comparing these results with those obtained in the analyzed samples, these fall within this range, except for S2 with an $\mathrm{a}_{\mathrm{w}}$ of 0.62 and LC with 0.65 . On the other hand, Alcalá (1977) in [31] mentions for Spanish honeys, a range of 0.40 to 0.60 . Honeys within this range can be considered safe against osmotolerant organisms such as fungi and yeast, which have the ability to grow in environments with low water activity $[22,33]$.

$\mathrm{pH}$ : In the normal composition of honey, several organic acids, mainly gluconic (70-90\%) are present, in addition to minor acids, such as acetic, butyric, citric, formic, lactic, malic, pyroglutamic, and succinic. These give honey an acid $\mathrm{pH}$ between 3.4 and 6.1 [34]. The $\mathrm{pH}$ of honey ranges from 3.2 to 5.5 and is generally less than 4 in nectar honey and more than 5 in honeydew honey [28]. The analyzed honeys had values between 3.73 and 4.16; therefore, all the analyzed samples were nectar honeys (Table 3, Figure 2). These $\mathrm{pH}$ values coincide with those reported for honeys of Venezuela, which register values between 3.79 and 4.98 [35].

Acidity: Deterioration refers to the alteration of characteristics of honey, a consequence of overheating, ageing, and fermentation, with this being a parameter that determines its acidity. Acidity is important since it indicates the degree of freshness of the honey; it is also related to fermentation by microorganisms [33]. The free acid content is an indirect measure of honey freshness and expresses the acidity independently of the acids present. The free acid is measured depending on the organic acids that honey naturally contains. Normal acidity values increase if the honey has fermented and this happens with elevated percentages of moisture where molds and yeast have developed. This parameter is important since if lactic, oxalic or formic acid have been used to combat Varroa, the acidity of the honey increases [26,36]. Moguel Ordoñez et al. [26] mention that in honeys from Tajonal (Viguiera dentata), low concentrations of free acid were found in the hive and gathering stages (24.5 and $24.0 \mathrm{mEq} / \mathrm{kg}$, respectively); however, during export, the acidity increased $(34.27 \mathrm{mEq} / \mathrm{kg})$, while in Tzitzilche (Gymnopodium floribundum) honeys, the lowest levels of free acidity were found in the hive and export stages (27.0 and $27.4 \mathrm{mEq} / \mathrm{kg}$, respectively), with this being $35.2 \mathrm{mEq} / \mathrm{kg}$ during collection in Yucatan; these values coincide with LC honey (25.05 $\mathrm{mEq} / \mathrm{kg})$ and S2 honey $(23.53 \mathrm{mEq} / \mathrm{kg})$. Studies carried out in Zulia (Venezuela) mention acidity values between 31.13 and 62.79 $\mathrm{mEq} / \mathrm{kg}$ [35], results that are similar to those found in the honeys analyzed in this study, such as EM honey with an acidity of 44.72 $\mathrm{mEq} / \mathrm{kg}$, EC honey with $45.26 \mathrm{mEq} / \mathrm{kg}$, S1 with $53.61 \mathrm{mEq} /$ $\mathrm{kg}$, PH with $45.94 \mathrm{mEq} / \mathrm{kg}$ and $\mathrm{C} 1$ with $47.01 \mathrm{mEq} / \mathrm{kg}$. NMXF-036-NORMEX-2006 mentions a maximum acidity of $40 \mathrm{mEq} /$ $\mathrm{kg}$. When compared with our results, five of the eight honeys do not comply with the standard (Table 3, Figure 2); however, this does not mean that the honey cannot be consumed since it is a natural food that is exposed to a number of variations, mainly in its composition [35]. Avilés Pérez and Matos Chamorro [33] analyzed

Table 3: Physico-chemical analysis of the honeys in the study.

\begin{tabular}{ccccccc}
\hline Honey sample & $\mathrm{a}_{\mathrm{w}}$ & $\mathrm{pH}$ & Acidity $\mathrm{mEq} / \mathrm{Kg}$ & Dextrins & Reducing sugars (\%) & Electrical conductivity $\mathrm{mS} / \mathrm{cm}^{*}$ \\
\hline LC & $0.65 \pm 0.00$ & $4.16 \pm 0.06$ & $18.79 \pm 0.44$ & $\mathrm{~A}$ & $79.00 \pm 0.01$ & $0.27 \pm 0.01$ \\
\hline ADA & $0.55 \pm 0.00$ & $3.77 \pm 0.04$ & $39.21 \pm 0.22$ & $\mathrm{~A}$ & $84.33 \pm 0.02$ & $0.35 \pm 0.00$ \\
\hline EM & $0.59 \pm 0.00$ & $3.90 \pm 0.01$ & $44.72 \pm 0.66$ & $\mathrm{~A}$ & $80.30 \pm 0.02$ & $0.51 \pm 0.02$ \\
\hline EC & $0.58 \pm 0.00$ & $3.88 \pm 0.10$ & $47.58 \pm 0.70$ & $\mathrm{~A}$ & $63.72 \pm 0.13$ & $0.47 \pm 0.02$ \\
\hline S1 & $0.59 \pm 0.00$ & $3.83 \pm 0.06$ & $52.3 \pm 0.18$ & $\mathrm{~A}$ & $83.90 \pm 0.33$ & $0.43 \pm 0.04$ \\
\hline S2 & $0.62 \pm 0.00$ & $3.82 \pm 0.04$ & $23.53 \pm 0.69$ & $\mathrm{~A}$ & $83.00 \pm 0.01$ & $0.41 \pm 0.01$ \\
\hline PH & $0.59 \pm 0.00$ & $3.73 \pm 0.05$ & $45.94 \pm 0.80$ & $\mathrm{~A}$ & $82.53 \pm 0.01$ & $0.36 \pm 0.01$ \\
\hline S2 & $0.62 \pm 0.00$ & $3.82 \pm 0.04$ & $23.53 \pm 0.69$ & $\mathrm{~A}$ & $83.00 \pm 0.01$ & $0.41 \pm 0.01$ \\
\hline C1 & $0.59 \pm 0.00$ & $3.74 \pm 0.04$ & $51.33 \pm 0.30$ & $\mathrm{~A}$ & $81.58 \pm 0.03$ & $0.34 \pm 0.01$ \\
\hline
\end{tabular}

$\mathrm{a}_{\mathrm{w}}$ : Water activity, "A: Absence, P: Presence 

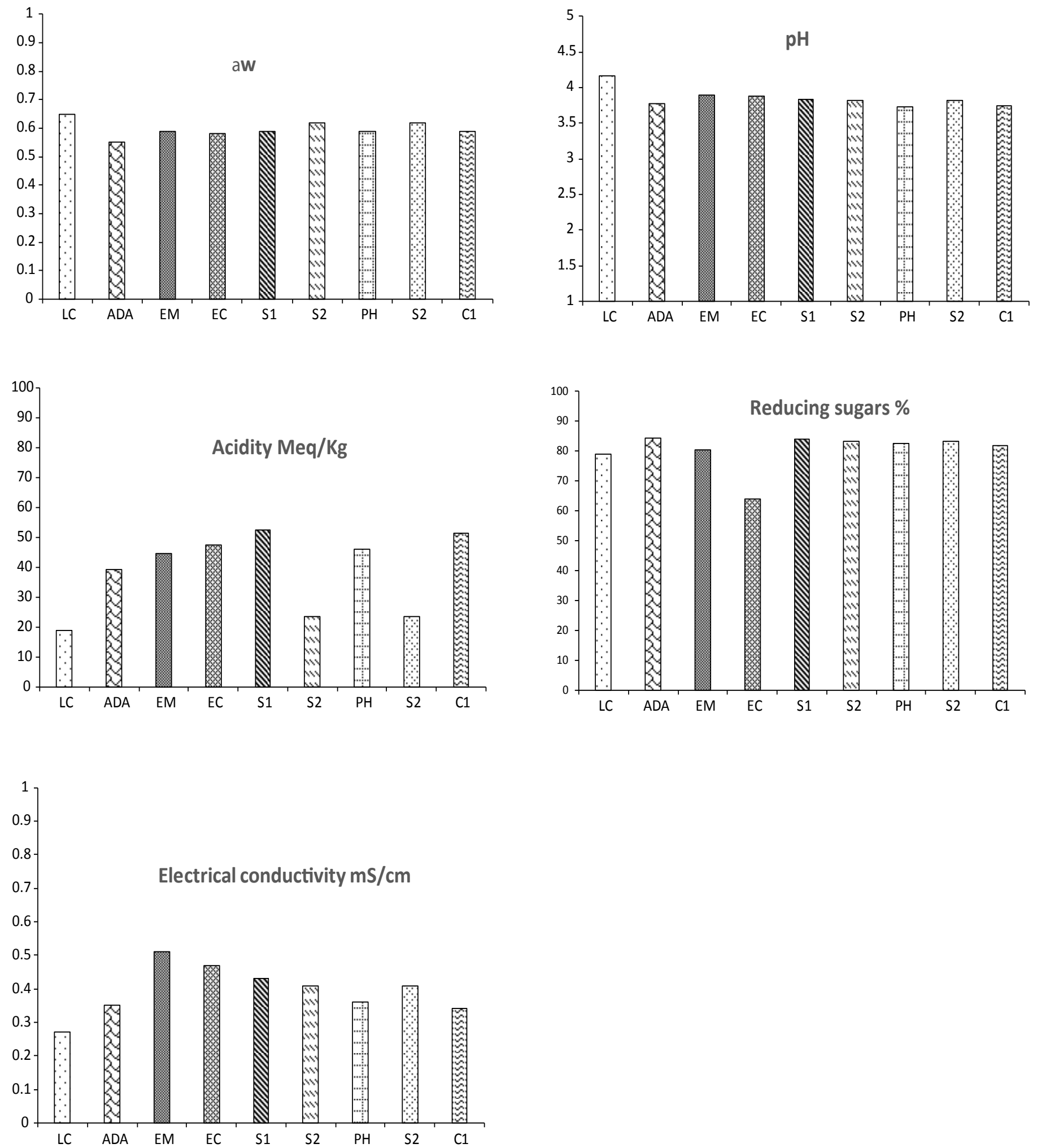

Figure 2: Physico-chemical analysis of eight honey samples in Nuevo Leon.

honeys of Peru and found values between 11.97 and $14.92 \mathrm{mEq} /$ $\mathrm{kg}$, values that are way below those of the honeys of this study. The acidity values of the studied honeys compared with other regions are different; these differences can be due to different factors such as overheating and the type of nectar used by the bee [18].

Dextrins: The adulteration of honey by adding commercial glucose is evidenced by the presence of dextrins. Honey by nature is mainly composed of sugars, because of this it has been the subject of adulterations with syrups, since these can be obtained very economically from starch hydrolysis. During this process dextrins are formed and the presence of high levels of these compounds in honey suggests the possibility that the food has been adulterated. Unlike starch dextrins, honey components similar to dextrins (higher sugars) do not react if the honey solution is acidified with hydrochloric acid and then mixed with alcohol $[37,38]$. This procedure is carried out so that the honey does not crystallize with time. Corn glucose contains substances that impede crystallization and since it is a product that costs less, it represents an economical 
benefit for people who commercialize honey [27]. In addition, most consumers believe that the presence of crystals in honey means that it is deteriorating, but this phenomenon is completely normal, since it occurs with time. According to the NMX-F-036NORMEX-2006 standard, the use of dextrins is not permitted in honey [19]. Table 3 shows the results obtained with dextrins; it was found that of all the honeys studied, none were turbid, ruling out the adulteration of these honeys.

Reducing sugars: One of the characteristics related to maturity is the determination of reducing sugars expressed in \% $(\mathrm{g} / 100 \mathrm{~g})$ which according to NMX-F-036-NORMEX-2006, the minimum acceptable value is $63.88 \%$ [19]. When comparing the results of this study with the standard, acceptable values of 63.72 and $84.33 \%$ were found, corresponding to EC and ADA honey, respectively (Table 3, Figure 2).

Electrical conductivity: Electrical conductivity is used to determine if the source of the honey is nectar or honeydew, monofloral honeys, and if the honey has probably been adulterated [22,39]. Honey is considered a secondary electric conductor since it contains salts, minerals, organic acids, and amino acids that confer this property. The values correlate with the mineral content and their measurement replaces ash percentage; also, electric conductivity is currently a more useful parameter. It is expressed in Siemens $\mathrm{cm}^{-1}$ or microsiemens $[21,40,41]$. According to the new international standards proposed by the International Honey Commission, the electrical conductivity of nectar or floral honeys must not exceed $0.80 \mathrm{mS} / \mathrm{cm}$; higher values correspond to honeydew and chestnut honeys, darker honeys, stronger flavor and less sweet $[22,40]$. The electrical conductivity of the analyzed honeys was between 0.2705 and $0.5045 \mathrm{mS} / \mathrm{cm}$ (Table 3, Figure 2). These values are within the national and international standards, meaning that the analyzed honeys are floral honeys.

\section{CONCLUSION}

According to the results obtained for the eight honey samples considering their pollen richness, the bromatological and physicochemical analyses, it was found that the honeys are within the National and International standards. On the other hand it is important to know the floral species that are present in the honey in order to determine their origin.

\section{REFERENCES}

1. Maurizio A. From the raw material to the finished product: Honey. Bee World. 1962;43(3):66-81.

2. Kirk SR, Sawyer R, Egan H. Composition and analysis of Pearson's food, (8thedn), Patria Editorial Group. 1992:236-242.

3. Ulloa JA, Mondragón CP, Rodríguez R, Reséndiz Vásquez JA, Rosas UP. Honey and its importance. Source Magazine. 2010;4:11-18.

4. Tellería MC. The pollen of honey, an indicator of its botanical and geographical origin. Sci Today. 2001;11:62-63.

5. Rodríguez I. Beekeeping in Mexico: The challenges of a sweet business. Agribusiness Magazine. 2009:61-75.

6. Ramírez J. The bees prodigy of nature. Biodiversitas. National Commission for the Knowledge and Use of Biodiversity. 1996;2:1-8.

7. Soto VCE. Study of monofloral honeys through palynological, physical, chemical and sensory analysis. Bachelor Thesis in Agronomy Universidad Austral de Chile Valdivia, Chile. 2008:138.

8. Sáenz de RC. Pollen and spores. Introduction to palynology and palynological vocabulary. H. Blume Editions,(1stedn), Madrid. 1978.
9. AOAC. Official Methods of Analysis of the Association of Analytical Chemists, (15thedn), AOAC, Washington DC, USA. 1997.

10. Avallone C, Montenegro S, Chifa C. Quality control of honey from the province of Chaco, Argentina and Apicultural Map. 2004.

11. AOAC. Official Methods of Analysis of the Association of Analytical Chemists (17thedn), AOAC, Washington DC, USA. 2000.

12. Bianchi E. Honey, characteristics and composition. Analysis and adulterations, Editorial UNSE-CEDIA, Santiago del Estero, Argentina. 1981.

13. Sainz C, Gómez C. Spanish honeys: characteristics and identification through pollen analysis. Mundi-Press Editions, Madrid, Spain. 1999.

14. Martínez HE, Ramírez AE. The commercial importance of the botanical origin of honey. Foundation for Sustainable Development. 2004.

15. Lezama MP, Rullan SM, Palma BE, Mayo VE, Santamaría PJ. Bromatology Course Program. University of Tabasco, Mexico. 2008.

16. Subovsky MJ, Sosa LA, Castillo AE, Marain D. Determination of moisture content in honey. XV Meeting of Scientific Technical Communications. Faculty of Agricultural Sciences UNNE, R005. 2004.

17. Suescún L, Vit P. Quality control of honey produced as a proposal for a mandatory community service project. Force Pharmaceutical Magazine. 2008;1:10-11.

18. Ramírez V, Domínguez J, Jiménez M, Herrera A, Abarca V. Manual of Good Practices of honey production. General Livestock Coordination (CGG) and National Health Service. Agroalimentary Safety and Quality (SENASICA), Mexico. 2005.

19. Mexican Standard NMX-F-036-2006 Honey Foods Test Specifications and Methods.

20. González-Miret ML, Terrab A, Hernanz D, Fernández-Recamales MA, Heredia FG. Multivariate correlation between color and mineral composition of honeys and by their botanical origin. J Agric Food Chem. 2005;53:2574-2580.

21. Avallone C, Montenegro S, Orellana A, Crazov A. Application of electrical conductivity as a method of determining ash in honey. Scientific and Technological Communications. National University of the North East. 2003.

22. Torrente GL. Bees as a bioindicator element. The use of pesticides as an important cause of their disappearance and contamination of honey. Physicochemical techniques for the Environment. UNED Environmental Sciences. 2011.

23. Hassan N, Razieh T, Ahmad M. Origin of honey proteins and method for its quality control. Pak J Bot. 2010;42:3221-3228.

24. Bachmann HE. Preliminary studies of bee honey characterization: Determination of carbohydrates by GC/MS and enzymatic analysis. Bachelor thesis, Austral University of Chile, Valdivia, Chile. 2007.

25. Caravaca-Rodríguez FP, Castel-Genis JM, Guzmán Guerrero JL, Delgado Pertiñez M, Guerreo Mena Y. Bases of animal production, (1stedn). Publications of the University of Seville, Spain. 2005:252.

26. Moguel-Ordoñez YB, Echazarreta C, Mora-Escobedo R. Physicochemical quality of honey bee Apis mellifera produced in the state of Yucatán during different stages of the production process and flowering types. TEC The Money MEX. 2005;43:323-334.

27. Ferrero Álvaro J, Morales R, Rosa Ignacio M, Veneciano E. Honey. National Technological University Villa María Regional Faculty. 2004

28. Prost-Jean P, Le Conte Y. Beekeeping knowledge of the bee handling of the hive. Editorial Mundi-Prensa. 2006:440-444. 
29. Krell R. Value-added products of beekeeping. Food and Agriculture Organization of the United Nations 1996;12:5-7.

30. Llorente MJ. Beekeeping products: Honey. Beekeeping World. 2001:1-5.

31. Salamanca GG, Pérez FC, Serra BAJ. Determination of water activity in Colombian honeys from the areas of Bocaya and Tolima. 2001.

32. Bush D, Keener K. Technologies for the conservation and processing of food. Department of Food Science. 2009.

33. Avilés Pérez HA, Matos Chamorro A. Comparative analysis of the physical, chemical, microbiological and organoleptic quality of honey (Apis mellifera) produced in different regions of Peru. J University Res. 2009;1:5-9.

34. Balanza ME, Ordoñez A, Barrera M. Total and lactonic acidity of honey from bees correlation with other parameters. National University of Cuyo San Martin, Argentina. 2000.

35. Piccirillo GA, Rodríguez BG, Ojeda RG. Study of some physical parameters in honeys harvested during the dry season of eight apicultural zones in the state of Zulia, Venezuela. Rev Fac Agro (LUZ). 1998;15:486-497.
36. Avalos H, Rodas E, Perdomo R, Quan J, Mejía D. Manual of Good Apicultural Practices in Central America. 2004.

37. Avallone CM, Montenegro S, Chifa C. Quality control in honeys from the province of Chaco-Argentina and apicultural map. Scientific and Technological Communications. 1999:1-4.

38. Aguas Y, Olivero R, Cury K. Determination of adulteration and honeys acceptability (Apis mellifera) market in Cartagena, Bolivar, Colombia. Colombian Journal of Animal Science-RECIA 2010;2(2):349-354.

39. Loveaux J, Pourtallier J, Vorwohl G. Methods of melissopalynology. Conductivité (Analytical methods for honey conductivity). Bull Apic Inf Doc Sci Tech Inf. 1973;16(7):139-153.

40. Corbella E, Cozzolino D, Ramallo G, Maidana M. Quality of honeys from Uruguay. The Agricultural Country. 2002:25-28.

41. Ciappini MC, Gatti MB, Di Vito MV, Baer J, Bellabarbo M, Erviti N, et al. Honey from the province of Santa Fe (Argentina) palynological, sensory and physicochemical determination according to phytogeographic provinces. Invention. 2009;12:143-150. 